ISSN 1678-3921

Journal homepage: www.embrapa.br/pab

For manuscript submission and journal contents, access: www.scielo.br/pab

\section{Nitrogen fertilization in off-season corn crop in different Brazilian Cerrado environments}

\begin{abstract}
The objective of this work was to assess the grain yield and the economic response of off-season corn (Zea mays) crop subjected to different combinations of starter and topdressing nitrogen fertilization, in the Brazilian Cerrado region. The experiment was carried out in a randomized complete block design in a $3 \times 4$ factorial arrangement $\left(0,45\right.$, and $90 \mathrm{~kg} \mathrm{ha}^{-1} \mathrm{~N}$ at sowing and $0,22.5,45$, and $90 \mathrm{~kg} \mathrm{ha}^{-1} \mathrm{~N}$ in topdressing as urea), in six environments, combining three sites and two sowing times. Grain yield was determined, and the response to total $\mathrm{N}$ applied as starter and topdressing was used to obtain a general model of the average trend of the technical and economic return of fertilization. The corn crop response varied according to the environment, and the observed yields were high. The application of $\mathrm{N}$ as a starter fertilizer increased corn yield and improved the effect of topdressing fertilization or even made it unnecessary. Fertilization with $90 \mathrm{~kg} \mathrm{ha}^{-1} \mathrm{~N}$ as urea promotes greater yield and economic return and improves $\mathrm{N}$ balance in the soybean/ off-season corn crop system.
\end{abstract}

Index terms: Zea mays, efficient $\mathrm{N}$ use, $\mathrm{N}$ requirement, second corn crop, soybean-corn succession.

\section{Adubação nitrogenada no milho safrinha em diferentes ambientes no Cerrado brasileiro}

Resumo - O objetivo deste trabalho foi avaliar a produtividade de grãos e a resposta econômica de milho (Zea mays) segunda safra submetido a diferentes combinações de adubações de $\mathrm{N}$ em semeadura e cobertura, na região do Cerrado brasileiro. $\mathrm{O}$ experimento foi conduzido em delineamento de blocos ao acaso, em arranjo fatorial $3 \times 4\left(0,45\right.$ e $90 \mathrm{~kg} \mathrm{ha}^{-1} \mathrm{de} \mathrm{N}$ na semeadura e 0 , 22,5, 45 e $90 \mathrm{~kg} \mathrm{ha}^{-1}$ de $\mathrm{N}$ em cobertura na forma de ureia), em seis ambientes, tendo-se combinado três locais e duas épocas de semeadura. A produtividade de grãos foi determinada, e a resposta às doses totais de $\mathrm{N}$ na semeadura $\mathrm{e}$ em cobertura foi usada para obter um modelo geral da tendência média de retorno técnico e econômico da adubação. A resposta da cultura de milho variou de acordo com o ambiente, e as produtividades observadas foram altas. A adubação nitrogenada na semeadura aumentou a produtividade do milho e melhorou o efeito da adubação em cobertura ou até a dispensou. A fertilização com $90 \mathrm{~kg} \mathrm{ha}^{-1}$ de $\mathrm{N}$ na forma de ureia proporciona maior produtividade e retorno econômico e melhora o balanço deste nutriente no sistema soja/milho segunda safra.

Termos para indexação: Zea mays, uso eficiente de N, requerimento de N, milho segunda safra, sucessão soja-milho. 


\section{Introduction}

The proper nitrogen management for corn (Zea mays L.) crops is difficult to determine, since the availability of the nutrient to the plants is affected by several uncontrollable factors, such as soil properties, rainfall, and temperature. Moreover, $\mathrm{N}$ requirements are directly linked to the expected yields (Morris et al., 2018). Therefore, all the environmental variables and biotic factors that influence yield potential or the $\mathrm{N}$ cycling can interfere in the amount of the nutrient that will need to be supplied by the fertilizer (Fontoura \& Bayer, 2009).

In the Cerrado biome, off-season corn is grown in several different subregions, sowed between January and March, encompassing a wide range of soil and climate conditions (Nóia Júnior \& Sentelhas, 2019a), which makes it difficult to reach a consensus on the decision criteria to recommend $\mathrm{N}$ fertilization. The uncertain climate conditions at the end of the rainy season affect both the corn yield potential (Simão et al., 2018) and the cycling of $\mathrm{N}$ from the residue of the preceding crop (Rossi et al., 2013), normally soybean [Glycine $\max$ (L.) Merr.]. The intensity of these interferences varies between years and crop sites, hindering the establishment of fertilizer recommendations applicable to all situations.

No-tillage farming and sowing immediately after soybean create favorable conditions for off-season corn nutrition. Besides the contribution of soil organic matter (SOM), there is a fast and greater release of nutrients by the decomposing leguminous crop residue, which has a low $\mathrm{C} / \mathrm{N}$ ratio (Redin et al., 2014). To adjust $\mathrm{N}$ fertilization for this crop succession in Brazil, each metric ton of soybean grain was considered to correspond to $17 \mathrm{~kg} \mathrm{ha}^{-1} \mathrm{~N}$ in the crop residue, which acts as a credit for the subsequent corn crop (Resende et al., 2018). Therefore, a yield of $3.6 \mathrm{Mg} \mathrm{ha}^{-1}$ soybean would indicate a surplus of up to $61 \mathrm{~kg} \mathrm{ha}^{-1} \mathrm{~N}$, which is an insufficient amount to meet the demand of offseason corn.

For a mean rate of $13.5 \mathrm{~kg} \mathrm{Mg}^{-1} \mathrm{~N}$ exported in corn grains (Silva et al., 2018; Duarte et al., 2019), $81 \mathrm{~kg} \mathrm{ha}^{-1}$ $\mathrm{N}$ would be needed to replenish the amount removed during the harvest of $6 \mathrm{Mg} \mathrm{ha}^{-1}$, a yield frequently achieved in the off-season (Conab, 2019). However, the effectiveness of corn in recovering $\mathrm{N}$ from fertilizers is not high and varies significantly, with a mean value of $63 \%$ under experimental conditions (Dobermann, 2005).

In general, off-season corn has responded to moderate $\mathrm{N}$ fertilizer rates, despite not showing consistent patterns between cropping sites and years. In the municipality of Rio Verde, in the state of Goiás, Brazil, Simão et al. (2018) found an average yield of 6.7 $\mathrm{Mg} \mathrm{ha}^{-1}$ grains with $50 \mathrm{~kg} \mathrm{ha}^{-1} \mathrm{~N}$ applied as topdressing, at the V3 phenological stage, over two years and two sowing times; the starter fertilizer varied from 0 to 50 $\mathrm{kg} \mathrm{ha}^{-1} \mathrm{~N}$. Studies in the region of Rio Paranaíba, in the state of Minas Gerais, also Brazil, showed that rates between 19 and $150 \mathrm{~kg} \mathrm{ha}^{-1} \mathrm{~N}$ promoted yields of 3.5 to 7.6 $\mathrm{Mg} \mathrm{ha}^{-1}$ (Gott et al., 2014; Sichocki et al., 2014). The limited response to $\mathrm{N}$ is usually due to the influence of climate, since drought reduces the yield potential and nutrient recovery efficiency of a crop, causing the additional amounts of $\mathrm{N}$ fertilizer to have a negligible effect on grain yield (Amado et al., 2013).

In a number of agricultural zones, however, the current technology used allows obtaining corn yields far above those achieved a few years ago for the soybean/ corn succession, and the mean off-season yield in the Southern-Western region of Brazil is already around 6.0 $\mathrm{Mg} \mathrm{ha}^{-1}$ (Conab, 2019). Although satisfactory yields are commonly reached with moderate doses of $\mathrm{N}$ in the Cerrado, in certain situations, there seems to be an imbalance between the rates of $\mathrm{N}$ fertilizer applied by the farmers and the $\mathrm{N}$ demand in the off-season for the obtained yields (Kappes, 2015; Fuentes et al., 2018). Therefore, despite the supply potential of the soil-straw component, the $\mathrm{N}$ balance may still be negative. This reinforces the need to determine crop responses and establish fertilization management criteria, so that the sustainability of the whole system is not compromised over time.

The objective of this work was to assess the grain yield and the economic response of off-season corn crop subjected to different combinations of starter and topdressing $\mathrm{N}$ fertilization, in the Brazilian Cerrado region.

\section{Materials and Methods}

The experiments were conducted in the off-season of 2015, in six environments in the Brazilian Cerrado, combining three sites and two sowing times of corn cultivated in succession to soybean (Table 1). The 
sites consisted of the municipalities of Rio Verde, in the state of Goiás, Sinop, in the state of Mato Grosso, and Vilhena, in the state of Rondônia. According to Köppen's classification, the climate in all locations is Aw, characteristic of a tropical savannah with a dry winter. Daily rainfall was recorded at automatic weather stations next to the experimental sites, and the rainfall data between January and July 2015 are presented in Figure 1.

For each environment, the experimental design was randomized complete blocks in a $3 \times 4$ factorial arrangement, with four replicates. The treatments consisted of three rates of $\mathrm{N}$ as starter fertilizer at sowing $\left(0,45\right.$, and $\left.90 \mathrm{~kg} \mathrm{ha}^{-1} \mathrm{~N}\right)$ and of four rates as topdressing $\left(0,22.5,45\right.$, and $\left.90 \mathrm{~kg} \mathrm{ha}^{-1} \mathrm{~N}\right)$, using common urea as a source. The experimental plots consisted of four $5.0-\mathrm{m}$ rows, spaced $0.5 \mathrm{~m}$ apart. The two center rows were considered the useful area, and $1.0 \mathrm{~m}$ at the edges were left as borders.

Phosphorus and potassium fertilization was evenly distributed in all treatments, applied in the furrow by the seeder, using a mixture of single superphosphate and potassium chloride to supply $50 \mathrm{~kg} \mathrm{ha}^{-1} \mathrm{P}_{2} \mathrm{O}_{5}, 25$ $\mathrm{kg} \mathrm{ha}^{-1} \mathrm{~S}$, and $50 \mathrm{~kg} \mathrm{ha}^{-1} \mathrm{~K}_{2} \mathrm{O}$. Nitrogen was manually applied according to each treatment. For the starter fertilization, urea was distributed in the sowing furrow and then covered with soil. Topdressing was applied to soil surface, banded along plant rows at the V3-4 phenological stage of three or four fullyunfolded leaves. The used corn cultivars were DKB $310 \mathrm{PRO} 2$, in the experiments in the municipalities of Rio Verde and Sinop, and DKB 390 PRO2, in Vilhena, at a density of 60,000 seeds per hectare. Herbicides, insecticides, and fungicides were applied according to the need of each crop environment, following the technical recommendations for corn (Pereira Filho, 2015).

Harvesting was carried out from June to July 2015, correcting grain yield to $13 \%$ moisture. The data obtained in each experimental environment were subjected to the analysis of variance. According to the significance of the F-test, starter $\mathrm{N}$ treatments were compared by Tukey's test, at $5 \%$ probability, and regression analyses were performed for $\mathrm{N}$ rates as topdressing, using the SAS statistical software (SAS Institute Inc., Cary, NC, USA).

The grain yield data as a function of the total $\mathrm{N}$ amounts applied as starter fertilizer and topdressing in the six environments were adjusted to a regression model representing the average trend of the corn crop response to $\mathrm{N}$ fertilization in the off-season conditions of the Cerrado region. This model made it possible

Table 1. Location, soil classification, soil fertility conditions in the $0-20$-cm layer, and sowing dates of off-season corn (Zea mays) crop in three experimental sites in the Brazilian Cerrado.

\begin{tabular}{|c|c|c|c|}
\hline Information & & Experimental site & \\
\hline Location & Comigo Technology Center & Embrapa Agrossilvipastoril & Embrapa Rondônia \\
\hline Municipality, state & Rio Verde, Goiás & Sinop, Mato Grosso & Vilhena, Rondônia \\
\hline Geographic coordinates & $17^{\circ} 45^{\prime} 52.6^{\prime \prime} \mathrm{S}, 51^{\circ} 02^{\prime} 14.6^{\prime \prime} \mathrm{W}$ & $11^{\circ} 52^{\prime} 22.1^{\prime \prime S}, 55^{\circ} 35^{\prime} 48.7^{\prime \prime} \mathrm{W}$ & $12^{\circ} 47^{\prime} 15.5^{\prime \prime} \mathrm{S}, 0^{\circ} 05^{\prime} 35.5^{\prime \prime} \mathrm{W}$ \\
\hline Altitude (m) & 748 & 384 & 610 \\
\hline Soil class & $\begin{array}{l}\text { Latossolo Vermelho distrófico } \\
\text { (Oxisol), clayey texture }\end{array}$ & $\begin{array}{l}\text { Latossolo Vermelho-Amarelo distrófico } \\
\text { típico (Oxisol), very clayey texture }\end{array}$ & $\begin{array}{l}\text { Latossolo Vermelho-Amarelo distrófico } \\
\text { (Oxisol), very clayey texture }\end{array}$ \\
\hline \multicolumn{4}{|l|}{ Soil analysis } \\
\hline Clay $\left(\mathrm{g} \mathrm{kg}^{-1}\right)$ & 390 & 580 & 740 \\
\hline $\mathrm{pH}_{\text {(water) }}$ & 5.8 & 5.3 & 5.4 \\
\hline $\operatorname{SOM}\left(\mathrm{g} \mathrm{kg}^{-1}\right)$ & 25 & 23 & 27 \\
\hline $\mathrm{P}_{\text {Mehlich }}\left(\mathrm{mg} \mathrm{dm}^{-3}\right)$ & 25 & 28 & 4.3 \\
\hline $\mathrm{K}_{\text {Mehlich }}\left(\mathrm{mg} \mathrm{dm}^{-3}\right)$ & 44 & 88 & 95 \\
\hline $\mathrm{Ca}\left(\mathrm{cmol}_{\mathrm{c}} \mathrm{dm}^{-3}\right)$ & 2.7 & 1.8 & 2.3 \\
\hline $\operatorname{Mg}\left(\mathrm{cmol}_{\mathrm{c}} \mathrm{dm}^{-3}\right)$ & 0.9 & 0.5 & 1.3 \\
\hline $\mathrm{H}+\mathrm{Al}\left(\mathrm{cmol}_{\mathrm{c}} \mathrm{dm}^{-3}\right)$ & 4.7 & 5.9 & 4.9 \\
\hline $\mathrm{CEC}\left(\mathrm{cmol}_{\mathrm{c}} \mathrm{dm}^{-3}\right)^{(1)}$ & 8.4 & 8.2 & 8.4 \\
\hline Base saturation (\%) & 44 & 31 & 46 \\
\hline Sowing date 1 & $2 / 3 / 2015$ & $2 / 12 / 2015$ & $2 / 20 / 2015$ \\
\hline Sowing date 2 & $2 / 25 / 2015$ & $3 / 3 / 2015$ & $3 / 12 / 2015$ \\
\hline
\end{tabular}

${ }^{(1)} \mathrm{CEC}$, cation exchange capacity. 
to estimate the economic optimum $\mathrm{N}$ rate (EONR), proposed by Alotaibi et al. (2018), by matching the first derivative of the yield function to the price ratio (9.7) between the unit cost of $\mathrm{N}(\mathrm{R} \$ 3.10$ per $\mathrm{kg}$ ) and the sales value of corn ( $\mathrm{R} \$ 0.32$ per $\mathrm{kg}$ ) in the year of the experiment. These average prices were obtained from the data of the states of Goiás, Mato Grosso, and Rondônia (Conab, 2018).

A partial $\mathrm{N}$ balance in the off-season corn crop was estimated from the mean response in the six environments, comparing situations with no $\mathrm{N}$ fertilizer and the EONR. Contributions from soil credits and fertilizer were considered as the amount of $\mathrm{N}$ supplied to the corn crop. Credits were estimated to be $61 \mathrm{~kg}$ $\mathrm{ha}^{-1} \mathrm{~N}$ released by the decomposition of the residue of the previous soybean crop, with a hypothetical yield of $3.6 \mathrm{Mg} \mathrm{ha}^{-1}$ (Resende et al., 2018), plus $31 \mathrm{~kg} \mathrm{ha}^{-1}$ $\mathrm{N}$ from the mineralization process for a mean SOM content of $25 \mathrm{~g} \mathrm{~kg}^{-1}$ (Fontoura \& Bayer, 2009). A 63\% fertilizer efficiency was assumed, in order to calculate
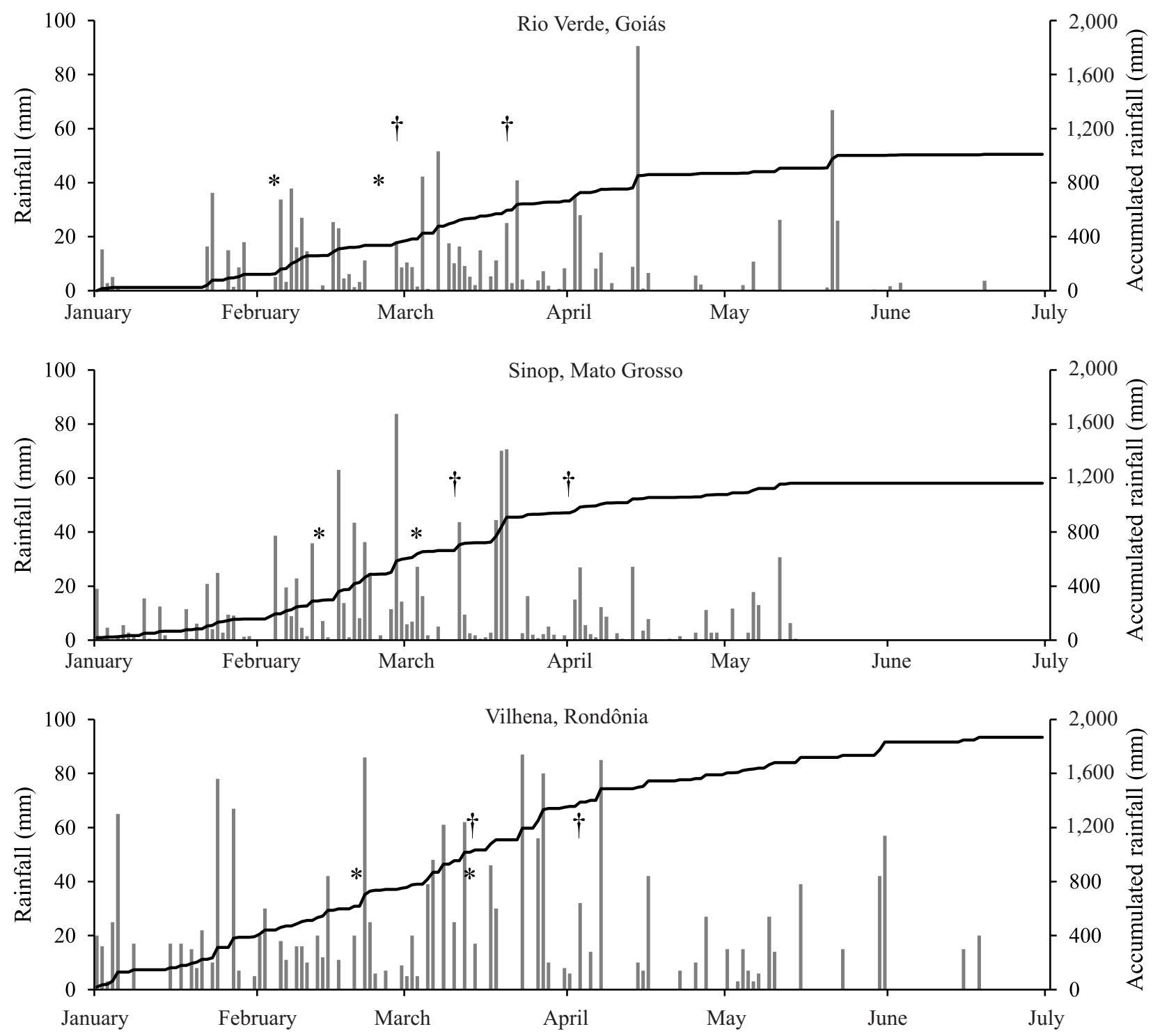

$$
\text { Rainfall }(\mathrm{mm})-\text { Accumulated rainfall }(\mathrm{mm}) * \text { Sowing date } \dagger \text { Top dressing date }
$$

Figure 1. Daily and accumulated rainfall between January and July 2015 in the experimental sites in the Brazilian Cerrado. 
the N proportion usable by the corn crop (Dobermann, 2005). The removal of $\mathrm{N}$ was determined considering the average rate of $13.1 \mathrm{~kg} \mathrm{Mg}^{-1}$ exported in the harvested grains of the off-season corn crop (Duarte et al., 2019) and the correspondent yield achieved in each condition. These yields were also used to estimate the amount of $\mathrm{N}$ extracted by corn, considering the average rate of $21.7 \mathrm{~kg} \mathrm{Mg}^{-1}$ reported for off-season crops (Simão et al., 2017).

\section{Results and Discussion}

The $\mathrm{N}$ fertilizer applied at sowing (starter $\mathrm{N}$ ) had a significant effect on corn grain yield in five of the six evaluated environments, but, as topdressing, only in four of them (Table 2). The initial analysis revealed a significant interaction between starter and topdressing $\mathrm{N}$ in the second sowing time in Sinop and in the first one in Vilhena. However, there is a greater probability of the crop responding to topdressing with the starter $\mathrm{N}$ rates of 0 or $45 \mathrm{~kg} \mathrm{ha}^{-1}$.

Yield was affected by topdressing in the absence of starter $\mathrm{N}$ in Rio Verde, under 0 and $45 \mathrm{~kg} \mathrm{ha}^{-1}$ starter $\mathrm{N}$ in Vilhena, and when $45 \mathrm{~kg} \mathrm{ha}^{-1} \mathrm{~N}$ were applied in the second sowing time in Sinop (Table 2). However, applying a larger amount of starter N (90 $\mathrm{kg} \mathrm{ha}^{-1}$ ) eliminated the influence of topdressing in all environments.

Grain yield was limited when $\mathrm{N}$ was not applied as starter fertilizer (Table 3). Supplying $45 \mathrm{~kg} \mathrm{ha}^{-1}$ as starter $\mathrm{N}$ caused significant yield gains in four of the six environments, with an increment ranging from 805 to $1,506 \mathrm{~kg} \mathrm{ha}^{-1}$ grains. However, the application of 90 $\mathrm{kg} \mathrm{ha}^{-1}$ starter $\mathrm{N}$ did not cause an additional cumulative gain.

Nitrogen fertilization often results in yield gains in off-season corn crops (Mar et al., 2003; Soratto et al., 2010; Simão et al., 2018), but different studies have reported variable response patterns to the amount and time of $\mathrm{N}$ application. In Dourados, in state of Mato Grosso do Sul, Brazil, Mar et al. (2003) obtained an increase of $1,497 \mathrm{~kg} \mathrm{ha}^{-1}$ grains by applying $30 \mathrm{~kg} \mathrm{ha}^{-1} \mathrm{~N}$, corresponding to an increase of $48.5 \%$, which reached $114.4 \%$ for a $\mathrm{N}$ rate of $120 \mathrm{~kg} \mathrm{ha}^{-1}$. However, the highest yield achieved in that case was $6,615 \mathrm{~kg} \mathrm{ha}^{-1}$, close to the lowest value of $6,475 \mathrm{~kg} \mathrm{ha}^{-1}$ recorded in the present study without $\mathrm{N}$ fertilizer in the second sowing time in Vilhena. Indeed, a growing yield potential has been observed for off-season corn in the main producing regions of the country, which certainly impacts the $\mathrm{N}$ requirements of the crop.

The climate conditions of the evaluated environments were favorable to the higher yields observed, even in the second sowing time, when compared with the modal performance of off-season corn in the Cerrado region. The amounts and distribution of rainfall during the cycle (Figure 1) were adequate to maintain soil moisture and to prevent ammonia volatilization from urea. Additionally to this, the nitrate loss by leaching is less intense in fine-textured soils, such as those of the cropping sites that are clayey to very clayey (Table 1). Moreover, nitrate leaching has been less problematic in

Table 2. Analysis of variance for off-season corn (Zea mays) grain yield, considering the effect of the interaction of the application of starter and topdressing nitrogen, in six environments in the Brazilian Cerrado.

\begin{tabular}{|c|c|c|c|c|c|c|c|}
\hline \multirow{2}{*}{$\begin{array}{l}\text { Source of } \\
\text { variation }^{(2)}\end{array}$} & \multirow[t]{2}{*}{$\mathrm{DF}^{(3)}$} & \multicolumn{6}{|c|}{ Mean squares in each environment ${ }^{(1)}$} \\
\hline & & RV1 & RV2 & SN1 & SN2 & VL1 & VL2 \\
\hline Block & 3 & 952,574 & 296,979 & 341,877 & 123,258 & $1,494,008$ & 305,252 \\
\hline Starter N (S) & 2 & 799,149 & $7,990,587 * *$ & $5,349,250 * *$ & $3,921,124^{*}$ & $1,985,276^{*}$ & $14,211,257^{* *}$ \\
\hline Topdressing $\mathrm{N}(\mathrm{T})$ & 3 & $1,868,055$ & $4,174,627 * *$ & $2,503,976^{*}$ & 78,580 & $2,049,442 * *$ & $12,752,400 * *$ \\
\hline $\mathrm{S} \times \mathrm{T}$ & 6 & $1,127,080$ & 737,121 & 713,713 & $2,472,821 *$ & $1,044,136^{*}$ & $1,004,154$ \\
\hline $\mathrm{T}$ in $\mathrm{S} 0$ & 3 & $3,888,659^{* *}$ & $3,562,306^{* *}$ & $1,727,729$ & 63,439 & $2,341,073 * *$ & $6,880,235^{* *}$ \\
\hline $\mathrm{T}$ in $\mathrm{S} 45$ & 3 & 220,372 & $1,019,971$ & $1,619,825$ & $3,111,319^{*}$ & $1,384,989^{*}$ & $6,128,423 * *$ \\
\hline $\mathrm{T}$ in $\mathrm{S} 90$ & 3 & 13,184 & $1,066,592$ & 583,848 & $1,849,465$ & 411,652 & $1,752,051$ \\
\hline Error & 33 & 833,674 & 585,414 & 826,075 & 858,501 & 455,440 & $1,032,074$ \\
\hline Mean $\left(\mathrm{kg} \mathrm{ha}^{-1}\right)$ & & 8,977 & 8,241 & 8,633 & 8,175 & 9,582 & 8,754 \\
\hline $\mathrm{CV}(\%)$ & & 10.17 & 9.28 & 10.53 & 11.33 & 7.04 & 11.61 \\
\hline
\end{tabular}

(1)RV1, RV2, SN1, SN2, VL1, and VL2, environments combining three cropping sites - municipalities of Rio Verde (RV), Sinop (SN), and Vilhena (VL) - and two sowing times (1 and 2). * and **Significant by the F-test, at 5 and $1 \%$ probability, respectively. ${ }^{(2)} \mathrm{S} 0, \mathrm{~S} 45$, and S90, starter $\mathrm{N}$ fertilizer rates of 0,45 and $90 \mathrm{~kg} \mathrm{ha}^{-1} .{ }^{(3)} \mathrm{DF}$, degrees of freedom. 
the off-season in relation to the spring-summer rainy season, which favors a greater recovery of fertilizer $\mathrm{N}$ by corn (Batista et al., 2011; Fuentes et al., 2018). These results also help to explain why topdressing was not always effective along to starter $\mathrm{N}$ fertilization in the present study (Table 2 and Figure 2).

The effect of $\mathrm{N}$ rates as topdressing, combined with each rate of starter fertilization (Figure 2), shows that, in most cases, no $\mathrm{N}$ at sowing resulted in a linear response to up to $90 \mathrm{~kg} \mathrm{ha}^{-1} \mathrm{~N}$ as topdressing, with yield increases between 18.4 and $30.4 \mathrm{~kg}$ grains for each kilogram of $\mathrm{N}$. These values give an idea of the agronomic efficiency of $\mathrm{N}$ fertilization in off-season corn. The gains are expressive, but the yields of 6,475 to $8,478 \mathrm{~kg} \mathrm{ha}^{-1}$ grains recorded with no $\mathrm{N}$ fertilizer were relatively high, reflecting the importance of the contribution of the soybean residue and SOM to meet the $\mathrm{N}$ demand of the off-season corn crop.

The observed variation in the agronomic efficiency of the corn crop is in line with the values reported in studies of $\mathrm{N}$ fertilization in the spring-summer using urea as a source. In Lages, in the state of Santa Catarina, Brazil, Sangoi et al. (2007) found increases of 13.9 to $38.8 \mathrm{~kg}$ grains per kilogram of $\mathrm{N}$ for a rate of $100 \mathrm{~kg} \mathrm{ha}^{-1} \mathrm{~N}$ applied at different times of the crop cycle. Panison et al. (2019) observed variations according to cultivar, growing season, and fertilization time. These authors also concluded that fertilization efficiency may be reduced under higher $\mathrm{N}$ rates, high SOM content, and yield levels lower than the expected.

In Rio Verde, both in the first and second sowing times, and in Vilhena, in the first one, starter $\mathrm{N}$ could eventually be substituted exclusively by topdressing,

Table 3. Grain yield response to starter nitrogen of offseason corn (Zea mays) crop grown in six ${ }^{(1)}$ environments in the Brazilian Cerrado ${ }^{(2)}$.

\begin{tabular}{lcccccc}
\hline \multirow{2}{*}{$\begin{array}{l}\text { Starter N } \\
\left(\mathrm{kg} \mathrm{ha}^{-1}\right)\end{array}$} & RV1 & RV2 & SN1 & SN2 & VL1 & VL2 \\
\hline 0 & $8,725 \mathrm{a}$ & $7,441 \mathrm{~b}$ & $8,149 \mathrm{~b}$ & $7,606 \mathrm{~b}$ & $9,200 \mathrm{~b}$ & $7,673 \mathrm{~b}$ \\
45 & $9,052 \mathrm{a}$ & $8,782 \mathrm{a}$ & $9,273 \mathrm{a}$ & $8,411 \mathrm{a}$ & $9,653 \mathrm{ab}$ & $9,179 \mathrm{a}$ \\
90 & $9,153 \mathrm{a}$ & $8,499 \mathrm{a}$ & $8,477 \mathrm{~b}$ & $8,507 \mathrm{a}$ & $9,894 \mathrm{a}$ & $9,408 \mathrm{a}$ \\
\hline Mean & 8,977 & 8,241 & 8,633 & 8,175 & 9,582 & 8,754 \\
\hline
\end{tabular}

(1)RV1, RV2, SN1, SN2, VL1, and VL2, environments combining three cropping sites - municipalities of Rio Verde (RV), Sinop (SN), and Vilhena (VL) - and two sowing times (1 and 2). ${ }^{(2)}$ Means followed by equal letters, in the columns, do not differ by Tukey's test, at $5 \%$ probability. although larger amounts of fertilizer would be required in some cases (Figure 2), implying a less efficient fertilization. In the second sowing time in Rio Verde, Sinop, and Vilhena, both agronomic efficiency and yield potential tended to be jeopardized when corn received $\mathrm{N}$ only as topdressing.

The rate of $45 \mathrm{~kg} \mathrm{ha}^{-1}$ starter $\mathrm{N}$ seems to be important to boost the crop's yield and even to improve the gains with topdressing, while the rate of $90 \mathrm{~kg} \mathrm{ha}^{-1}$ starter $\mathrm{N}$ makes topdressing ineffective (Figure 2). Therefore, the studied off-season environments supported corn response to moderate $\mathrm{N}$ amounts, with little or no advantage due to higher fertilization rates. This response pattern has been frequently observed, being largely attributed to climate factors that result in a lower yield potential (Duarte \& Kappes, 2015). It should be noted that a significant part of the $\mathrm{N}$ supply for off-season corn comes from the credits of the previous spring/summer soybean crop, which, as previously mentioned, can be estimated at around 17 $\mathrm{kg} \mathrm{N}$ for each metric ton of soybean grain produced (Resende et al., 2018).

Water availability in the soil declines over the course of the off-season corn cycle in the Cerrado region, which limits the ability of the crop to absorb nutrients (Resende et al., 2018). In addition, there is high weather variability regarding solar radiation and air temperature, inhibiting the photosynthetic metabolism and yield potential of the corn plants (Nóia Júnior \& Sentelhas, 2019b). Although modern cultivars are physiologically able to uptake high amounts of $\mathrm{N}$ (Bender et al., 2013; Silva et al., 2018), there is less need for fertilization in the off-season, compared with the spring-summer cropping, due to the lower yields achieved (Ragagnin et al., 2010; Soratto et al., 2010; Simão et al., 2017).

The results of the present study corroborate those of Duarte et al. (2017), who conducted experiments with off-season corn in the states of São Paulo and Mato Grosso, Brazil. When comparing topdressing with or without the application of $39 \mathrm{~kg} \mathrm{ha}^{-1} \mathrm{~N}$ at sowing, the authors found that there was a reduction in crop yield potential and in the efficiency of $\mathrm{N}$ fertilization without this initial supply of the nutrient. Therefore, part of the $\mathrm{N}$ needs to be applied as starter, in rates from 30 to $40 \mathrm{~kg} \mathrm{ha}^{-1}$, because the demand is high in the initial growth stages when the root system has yet to expand. Furthermore, $\mathrm{N}$ uptake must occur during the 

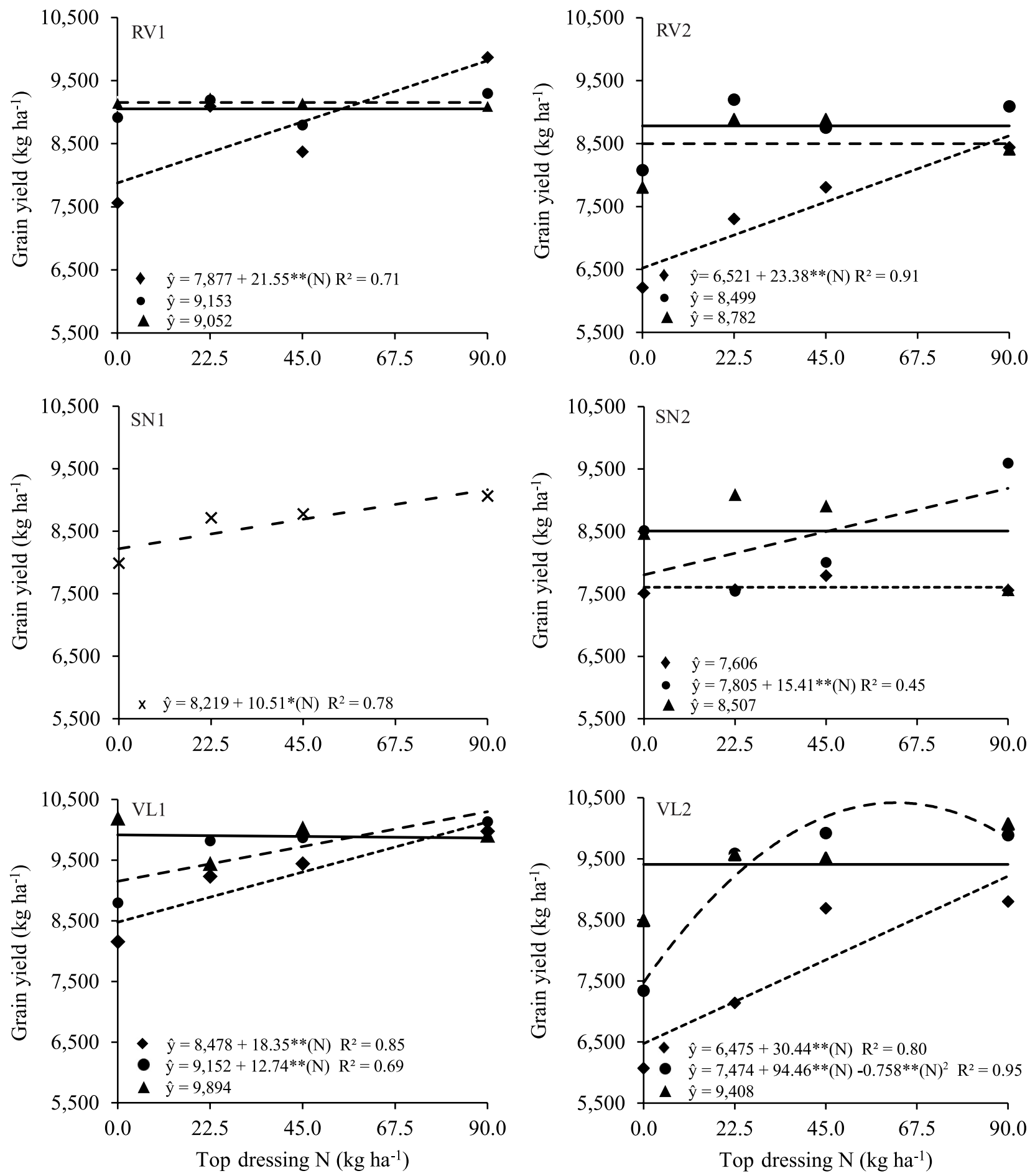

$$
\begin{array}{ll}
\cdots \cdots 0 \mathrm{~kg} \mathrm{ha}^{-1} \text { starter } \mathrm{N} & \mathbf{\Delta}-90 \mathrm{~kg} \mathrm{ha}^{-1} \text { starter } \mathrm{N} \\
--45 \mathrm{~kg} \mathrm{ha}^{-1} \text { starter } \mathrm{N} & \times-- \text { Mean of the starter } \mathrm{N} \text { rates }
\end{array}
$$

Figure 2. Grain yield of off-season corn (Zea mays) crop in function of the combination between starter and topdressing nitrogen in six environments in the Brazilian Cerrado. RV1, RV2, SN1, SN2, VL1, and VL2, environments combining three cropping sites - municipalities of Rio Verde (RV), Sinop (SN), and Vilhena (VL) - and two sowing times (1 and 2). 
first phases of the cycle since the corn yield potential is established early (Ritchie et al., 2003; Bender et al., 2013; Resende et al., 2018).

Therefore, if fertilization is delayed, adequate $\mathrm{N}$ levels for plant uptake are not always guaranteed since soil moisture may not be sufficient in the most advanced stages of the crop. In this regard, Mar et al. (2003) tested $\mathrm{N}$ rates ranging from 30 to $150 \mathrm{~kg} \mathrm{ha}^{-1}$, fully or partially applied at sowing, in Dourados, in the state of Mato Grosso do Sul, Brazil, and found that rates up to $60 \mathrm{~kg} \mathrm{ha}^{-1} \mathrm{~N}$ could be applied once at sowing.

Although a standardized response was not observed in the experiments carried out in the states of Goiás, Mato Grosso, and Rondônia (Figure 2), the aggregated data of the six environments revealed average productive performance as a function of the total $\mathrm{N}$ in the fertilization (Figure 3). Therefore, it is plausible to state that data dispersion showed a trend that summarizes the potential of corn response to $\mathrm{N}$ in the off-season conditions of the Cerrado region.

According to the response model (Figure 3), the $\mathrm{N}$ rate for maximum yield was estimated to be around $124 \mathrm{~kg} \mathrm{ha}^{-1}$, which would result in a yield of $9,403 \mathrm{~kg}$ ha $^{-1}$ grains, corresponding to an increase of $2,220 \mathrm{~kg}$ $\mathrm{ha}^{1}$ and a fertilization efficiency of $17.9 \mathrm{~kg}$ grains for each kilogram of $\mathrm{N}$ applied. The EONR that produced the highest net revenue (Alotaibi et al., 2018) was estimated to be $90 \mathrm{~kg} \mathrm{ha}^{-1}$, based on the yield response model and the price ratio of 9.7 between the $\mathrm{N}$ cost and the sales value of the grain in 2015. This rate of fertilization would promote a yield of $9,234 \mathrm{~kg} \mathrm{ha}^{-1}$,
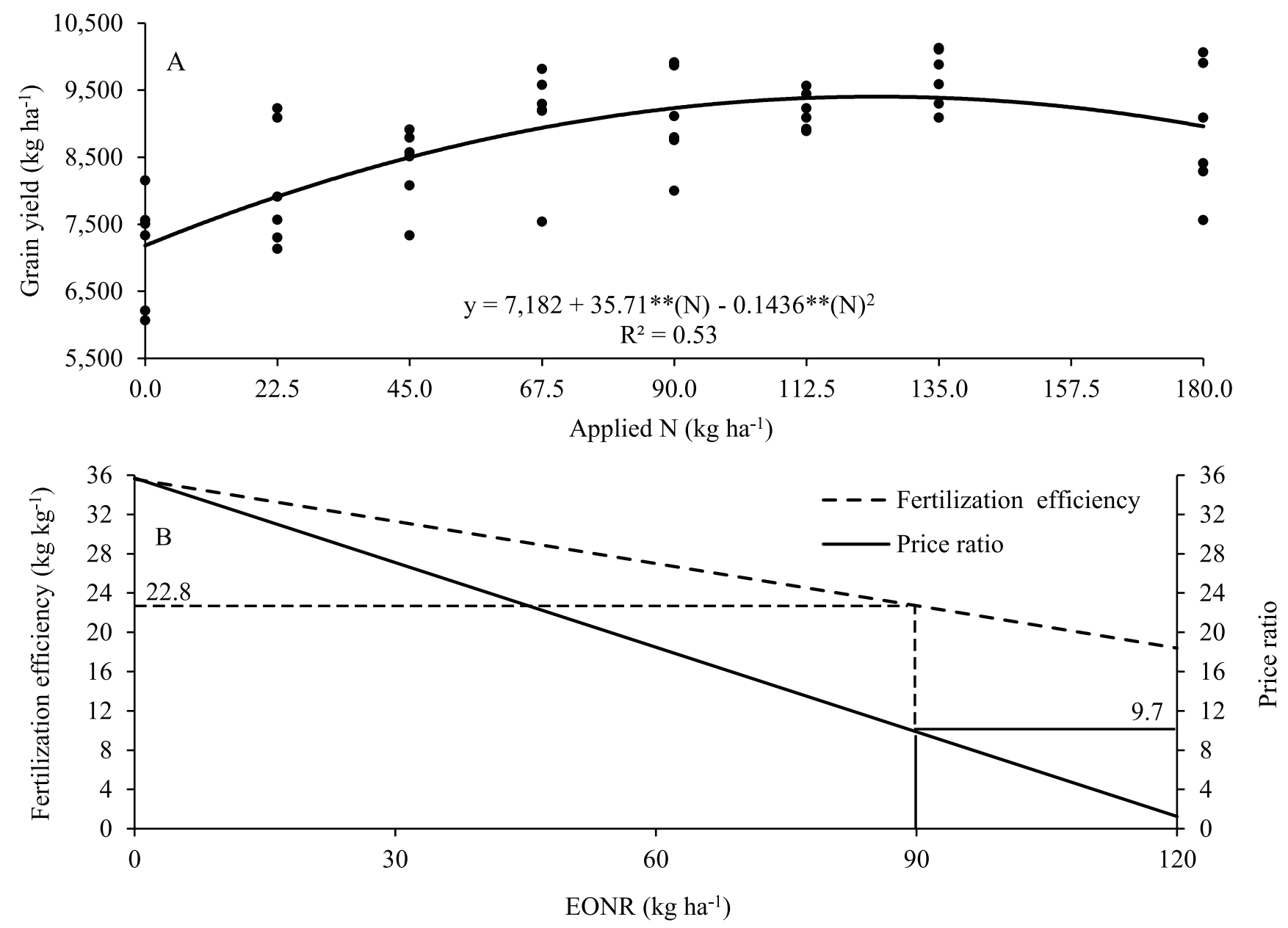

Figure 3. Mean productive performance of off-season corn (Zea mays) in six environments in the Brazilian Cerrado, as a function of the total $\mathrm{N}$ applied as starter and topdressing fertilizer (A), as well as fertilization efficiency at the economic optimum $\mathrm{N}$ rate (EONR) for the $9.7 \mathrm{~N} /$ grain price ratio in 2015 (B). 
with an increase of $2,051 \mathrm{~kg}$ ha ${ }^{1}$ and efficiency of 22.8 $\mathrm{kg}$ grains for each kilogram of $\mathrm{N}$.

The N/grain price ratio is inversely proportional to the EONR, but directly proportional to fertilization efficiency. Based on the average response pattern to $\mathrm{N}$ in the studied environments, it is possible to visually estimate the EONR and the respective index of fertilization efficiency for other price ratios resulting from variations in the market (Figure 3). Therefore, it is possible to adjust $\mathrm{N}$ fertilizer recommendations to ensure profitability in the event of a significant change in the cost of the fertilizer or in the value of the corn grain.

Many producers tend to reduce fertilization in the off-season crop, causing $\mathrm{N}$ deficits that compromise the sustainability of the soybean/corn system (Kappes, 2015). According to the balance estimated in the present study, the EONR of $90 \mathrm{~kg} \mathrm{ha}^{-1}$ was still less than the amount that would be needed to fully replenish

Table 4. Partial nitrogen balance in the off-season corn (Zea mays) crop, based on the average response to $\mathrm{N}$ fertilization in six environments in the Brazilian Cerrado.

\begin{tabular}{|c|c|c|}
\hline \multirow[t]{2}{*}{ Balance parameter } & \multicolumn{2}{|c|}{ Nitrogen fertilization } \\
\hline & Without N & $\begin{array}{c}\text { Economic } \\
\text { optimum rate }\end{array}$ \\
\hline & \multicolumn{2}{|c|}{ 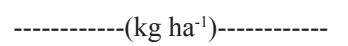 } \\
\hline 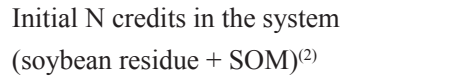 & 92.0 & 92.0 \\
\hline $\mathrm{N}$ available from fertilizer ${ }^{(3)}$ & - & 57.0 \\
\hline Grain yield & $7,183.0$ & $9,234.0$ \\
\hline Yield increment from fertilization & - & $2,051.0$ \\
\hline $\mathrm{N}$ extracted by corn ${ }^{(4)}$ & 156.0 & 200.0 \\
\hline $\mathrm{N}$ exported by corn ${ }^{(5)}$ & 94.0 & 121.0 \\
\hline $\mathrm{N}$ content remaining in the corn straw ${ }^{(6)}$ & $62.0(67.0)$ & $79.0(86.0)$ \\
\hline $\begin{array}{l}\text { Input and output balance of } \mathrm{N} \text { for the } \\
\text { corn } \text { crop }^{(7)}\end{array}$ & -2.0 & 28.0 \\
\hline $\begin{array}{l}\text { (1) } \mathrm{N} \text { rate related to the highest net rev } \\
\text { model (Figure } 3 \mathrm{~A} \text { ), calculated to be } 901 \\
\mathrm{~N} \text { released by the decomposition of the } \\
\text { for a hypothetical yield of } 3.6 \mathrm{Mg} \text { ha } \\
\text { mineralization process for a mean soi } \\
\text { of } 25 \mathrm{~g} \mathrm{~kg}^{-1} \text {. }^{(3)} \text { Considering an average } \\
\text { corn. }{ }^{(4)} \mathrm{Considering} \text { an average extracti } \\
\text { corn grains produced in the off-season. } \\
\text { of } 13.1 \mathrm{~kg} \mathrm{Mg}^{-1} \mathrm{~N} \text { in the harvested gra } \\
{ }^{(6)} \text { Corresponds to the extraction minu } \\
\text { between parentheses indicate the percen } \\
\text { initial credits of } \mathrm{N} \text { in the system. }{ }^{(7)} \mathrm{Sum} \\
\text { the fertilizer, minus the } \mathrm{N} \text { removal in th }\end{array}$ & $\begin{array}{l}\text { ue, according } \\
\text { ha-1 N. }{ }^{(2)} \text { Esti } \\
\text { soybean }(G l y c \\
\text { plus } 31 \mathrm{~kg} \\
\text { organic matte } \\
\text { ertilizer effici } \\
\text { of } 21.7 \mathrm{~kg} \mathrm{~N} \\
\text { Considering a } \\
\text { is of the off-s } \\
\text { export of N } \\
\text { ge remaining } \\
\text { f the initial cr } \\
\text { corn grain har }\end{array}$ & $\begin{array}{l}\text { to the response } \\
\text { late of } 61 \mathrm{~kg} \mathrm{ha}^{-1} \\
\text { ne max) residue } \\
\mathrm{ag}^{-1} \mathrm{~N} \text { from the } \\
\text { (SOM) content } \\
\text { ency of } 63 \% \text { for } \\
\text { er metric ton of } \\
\mathrm{n} \text { average export } \\
\text { eason corn crop. } \\
\text { y corn. Values } \\
\text { in relation to the } \\
\text { dits and } \mathrm{N} \text { from } \\
\text { est. }\end{array}$ \\
\hline
\end{tabular}

the $\mathrm{N}$ removal of $121 \mathrm{~kg} \mathrm{ha}^{-1}$ in the corresponding corn harvest (Table 4). However, that EONR makes it possible to reconcile a significant yield gain with a more balanced $\mathrm{N}$ supply to the system, restoring part of the $\mathrm{N}$ credits via corn straw and preventing deficits. When the nutrient supply is reduced in an extreme situation without $\mathrm{N}$ fertilizer, the balance tends to become negative, which may lead to the depletion of system's $\mathrm{N}$ reserves over successive crop cycles.

Neglecting $\mathrm{N}$ fertilization in off-season corn causes negative impacts, not only on grain yield, but primarily on stocks of native $\mathrm{N}$ in the soil, which leads to SOM degradation (Conceição et al., 2005; Singh, 2018; Rocha et al., 2020), compromising the yield potential of the soybean/corn system as a whole.

Although the ideal would be to establish $\mathrm{N}$ fertilization rates according to criteria based on indicators obtained locally, avoiding generic recommendations, the results of the present study showed a frequent response of the off-season corn crop in the Cerrado region to up to $90 \mathrm{~kg} \mathrm{ha}^{-1} \mathrm{~N}$. Besides not promoting yield increase, the application of higher $\mathrm{N}$ rates tends not to be economically viable. In any case, the $\mathrm{N}$ supply proportionally adjusted to off-season corn yield is essential for the maintenance of soil fertility and the sustainability of annual crop systems in the Brazilian Cerrado.

\section{Conclusions}

1. The off-season corn (Zea mays) crop grown in different environments in the Brazilian Cerrado shows varying responses to nitrogen fertilization.

2. Applying $\mathrm{N}$ as starter fertilizer boosts corn yield and improves the effect of topdressing or even makes its application unnecessary.

3. Fertilization with $90 \mathrm{~kg} \mathrm{ha}^{-1} \mathrm{~N}$ as urea promotes greater yield and an optimum economic return, also favoring the $\mathrm{N}$ balance in the soybean (Glycine max)/ corn system.

\section{Acknowledgments}

To Cooperativa Agroindustrial dos Produtores Rurais do Sudoeste Goiano (Comigo), for the used field and support in the conduction of the experiments in Rio Verde, in the state of Goiás, Brazil; and to Conselho Nacional de Desenvolvimento Científico e 
Tecnológico (CNPq), for scholarships granted to the first and last authors.

\section{References}

ALOTAIBI, K.D.; CAMBOURIS, A.N.; ST. LUCE, M.; ZIADI, N.; TREMBLAY, N. Economic optimum nitrogen fertilizer rate and residual soil nitrate as influenced by soil texture in corn production. Agronomy Journal, v.110, p.2233-2242, 2018. DOI: https://doi.org/10.2134/agronj2017.10.0583.

AMADO, T.J.C.; VILLALBA, E.O.H.; BORTOLOTTO, R.P.; SANTI, A.L.; LEÓN, E.A.B.; MENEFEE, D.; KUNZ, J. Efficiency of nitrogen fertilizer applied at corn sowing in contrasting growing seasons in Paraguay. Revista Brasileira de Ciência do Solo, v.37, p.1641-1650, 2013. DOI: https://doi.org/10.1590/S0100-06832013000600020.

BATISTA, K.; DUARTE, A.P.; CECCON, G.; DE MARIA, I.C.; CANTARELLA, H. Acúmulo de matéria seca e de nutrientes em forrageiras consorciadas com milho safrinha em função da adubação nitrogenada. Pesquisa Agropecuária Brasileira, v.46, p.1154-1160, 2011. DOI: https://doi.org/10.1590/S0100204X2011001000006.

BENDER, R.R.; HAEGELE, J.W.; RUFFO, M.L.; BELOW, F.E. Nutrient uptake, partitioning, and remobilization in modern, transgenic insect-protected maize hybrids. Agronomy Journal, v.105, p.161-170, 2013. DOI: https://doi.org/10.2134/ agronj2012.0352.

CONAB. Companhia Nacional de Abastecimento. Preços agropecuários. Brasília, 2018. Available at: $<$ https://www.conab. gov.br/info-agro/precos?view $=$ default $>$. Accessed on: Oct. 24 2018.

CONAB. Companhia Nacional de Abastecimento. Série histórica das safras. Brasília, 2019. Available at: <https://www.conab. gov.br/info-agro/safras/serie-historica-das-safras?start $=20>$. Accessed on: Apr. 222019.

CONCEIÇÃO, P.C.; AMADO, T.J.C.; MIELNICZUK, J.; SPAGNOLLO, E. Qualidade do solo em sistemas de manejo avaliada pela dinâmica da matéria orgânica e atributos relacionados. Revista Brasileira de Ciência do Solo, v.29, p.777-788, 2005. DOI: https://doi.org/10.1590/S0100-06832005000500013.

DOBERMANN, A.R. Nitrogen use efficiency - state of the art. 2005. Available at: <https://digitalcommons.unl.edu/ agronomyfacpub/316>. Accessed on: Apr. 172019.

DUARTE, A.P.; ABREU, M.F. de; FRANCISCO, E.A.B.; GITTI, D. de C.; BARTH, G.; KAPPES, C. Reference values of grain nutrient content and removal for corn. Revista Brasileira de Ciência do Solo, v.43, e0180102, 2019. DOI: https://doi.org/10.1590/18069657rbcs20180102.

DUARTE, A.P.; CANTARELLA, H.; KAPPES, C. Adubação de arranque no milho. Revista Cultivar - Grandes Culturas, v.213, p.11-13, 2017.

DUARTE, A.P.; KAPPES, C. Evolução dos sistemas de cultivo de milho no Brasil. Informações Agronômicas, n.152, p.15-18, 2015.
FONTOURA, S.M.V.; BAYER, C. Adubação nitrogenada para alto rendimento de milho em plantio direto na região centro-sul do Paraná. Revista Brasileira de Ciência do Solo, v.33, p.1721-1732, 2009. DOI: https://doi.org/10.1590/S0100-06832009000600021.

FUENTES, L.F.G.; SOUZA, L.C.F. de; SERRA, A.P.; RECH, J.; VITORINO, A.C.T. Corn agronomic traits and recovery of nitrogen from fertilizer during crop season and off-season. Pesquisa Agropecuária Brasileira, v.53, p.1158-1166, 2018. DOI: https://doi.org/10.1590/s0100-204x2018001000009.

GOTT, R.M.; SICHOCKI, D.; AQUINO, L.A.; XAVIER, F.O.; SANTOS, L.P.D. dos; AQUINO, R.F.B.A. de. Fontes e épocas de aplicação de nitrogênio no milho safrinha. Revista Brasileira de Milho e Sorgo, v.13, p.24-34, 2014. DOI: https://doi.org/10.18512/1980-6477/rbms.v13n1p24-34.

KAPPES, C. Inserção do milho safrinha em sistemas de produção no Mato Grosso. In: FUNDAÇÃO MATO GROSSO. Boletim de Pesquisa 2015/2016. Santa Cruz do Sul: Gazeta, 2015. p.136-173.

MAR, G.D. do; MARCHETTI, M.E.; SOUZA, L.C.F. de; GONÇALVES, M.C.; NOVELINO, J.O. Produção do milho safrinha em função de doses e épocas de aplicação de nitrogênio. Bragantia, v.62, p.267-274, 2003. DOI: https://doi.org/10.1590/ S0006-87052003000200012.

MORRIS, T.F.; MURRELL, T.S.; BEEGLE, D.B.; CAMBERATO, J.J.; FERGUSON, R.B.; GROVE, J.; KETTERINGS, Q.; KYVERYGA, P.M.; LABOSKI, C.A.M.; MCGRATH, J.M.; MEISINGER, J.J.; MELKONIAN, J.; MOEBIUS-CLUNE, B.N.; NAFZIGER, E.D.; OSMOND, D.; SAWYER, J.E.; SCHARF, P.C.; SMITH, W.; SPARGO, J.T.; VAN ES, H.M; YANG, H. Strengths and limitations of nitrogen rate recommendations for corn and opportunities for improvement. Agronomy Journal, v.110, p.137, 2018. DOI: https://doi.org/10.2134/agronj2017.02.0112.

NÓIA JÚNIOR, R. de S.; SENTELHAS, P.C. Soybean-maize off-season double crop system in Brazil as affected by El Niño Southern oscillation phases. Agricultural Systems, v.173, p.254267, 2019a. DOI: https://doi.org/10.1016/j.agsy.2019.03.012.

NÓIA JÚNIOR, R. de S.; SENTELHAS, P.C. Soybean-maize succession in Brazil: impacts of sowing dates on climate variability, yields and economic profitability. European Journal of Agronomy, v.103, p.140-151, 2019b. DOI: https://doi.org/10.1016/j.eja.2018.12.008.

PANISON, F.; SANGOI, L.; DURLI, M.M.; LEOLATO, L.S.; COELHO, A.E.; KUNESKI, H.F.; LIZ, V.O. de. Timing and splitting of nitrogen side-dress fertilization of early corn hybrids for high grain yield. Revista Brasileira de Ciência do Solo, v.43, e0170338, 2019. DOI: https://doi.org/10.1590/18069657rbcs20170338.

PEREIRA FILHO, I.A. (Ed.). Sistemas de Produção Embrapa: cultivo do milho. 9.ed. Brasília: Embrapa, 2015. Available at: $<$ https://www.spo.cnptia.embrapa.br/home $>$. Accessed on: Dec. 182020

RAGAGNIN, V.A.; SENA JÚNIOR, D.G. de; KLEIN, V.; LIMA, R.S.; COSTA, M.M.; OLIVEIRA NETO, O.V. de. Adubação nitrogenada em milho safrinha sob plantio direto em Jataí-GO.

Global Science and Technology, v.3, p.70-77, 2010. 
REDIN, M.; RECOUS, S.; AITA, C.; DIETRICH, G.; SKOLAUDE, A.C.; LUDKE, W.H.; SCHMATZ, R.; GIACOMINI, S.J. How the chemical composition and heterogeneity of crop residue mixtures decomposing at the soil surface affects $\mathrm{C}$ and $\mathrm{N}$ mineralization. Soil Biology and Biochemistry, v.78, p.65-75, 2014. DOI: https://doi.org/10.1016/j.soilbio.2014.07.014.

RESENDE, A.V. de; BORGHI, E.; GONTIJO NETO, M.M.; ABREU, S.C.; SANTOS, F.C. dos; COELHO, A.M. Manejo de nutrientes no cultivo de milho segunda safra na região do cerrado. Revista Plantio Direto \& Tecnologia Agrícola, v.28, p.19-29, 2018.

RITCHIE, S.W.; HANWAY, J.J.; BENSON, G.O. Como a planta de milho se desenvolve. Informações Agronômicas, n.103, p.120, 2003.

ROCHA, K.F.; SOUZA, M. de; ALMEIDA, D.S.; CHADWICK, D.R.; JONES, D.L.; MOONEY, S.J.; ROSOLEM, C.A. Cover crops affect the partial nitrogen balance in a maize-forage cropping system. Geoderma, v.360, art.114000, 2020. DOI: https://doi.org/10.1016/j.geoderma.2019.114000.

ROSSI, C.Q.; PEREIRA, M.G.; GIÁCOMO, S.G.; BETTA, M.; POLIDORO, J.C. Decomposição e liberação de nutrientes da palhada de braquiária, sorgo e soja em áreas de plantio direto no cerrado goiano. Semina: Ciências Agrárias, v.34, p.1523-1534, 2013. DOI: https://doi.org/10.5433/1679-0359.2013v34n4p1523.

SANGOI, L.; ERNANI, P.R.; SILVA, P.R.F. da. Maize response to nitrogen fertilization timing in two tillage systems in a soil with high organic matter content. Revista Brasileira de Ciência do Solo, v.31, p.507-517, 2007. DOI: https://doi.org/10.1590/S010006832007000300011 .
SICHOCKI, D.; GOTT, R.M.; FUGA, C.A.G.; AQUINO, L.A.; RUAS, R.A.A.; NUNES, P.H.M.P. Resposta do milho safrinha à doses de nitrogênio e de fósforo. Revista Brasileira de Milho e Sorgo v.13, p.48-58, 2014. DOI: https://doi.org/10.18512/19806477/rbms.v13n1p48-58.

SILVA, C.G.M.; RESENDE, A.V. de; GUTIÉRREZ, A.M.; MOREIRA, S.G.; BORGHI, E.; ALMEIDA, G.O. Macronutrient uptake and export in transgenic corn under two levels of fertilization. Pesquisa Agropecuária Brasileira, v.53, p.1363-1372, 2018. DOI: https://doi.org/10.1590/s0100$204 \times 2018001200009$.

SIMÃO, E. de P.; RESENDE, A.V. de; GONTIJO NETO, M.M.; BORGHI, E.; MARTINS, D.C.; VANIN, Á. Demanda de nutrientes pelo milho safrinha em função da época de semeadura e adubação. Revista Brasileira de Milho e Sorgo, v.16, p.481494, 2017. DOI: https://doi.org/10.18512/1980-6477/rbms. v16n3p481-494.

SIMÃO, E. de P.; RESENDE, A.V. de; GONTIJO NETO, M.M.; BORGHI, E.; VANIN, Á. Resposta do milho safrinha à adubação em duas épocas de semeadura. Revista Brasileira de Milho e Sorgo, v.17, p.76-90, 2018. DOI: https://doi.org/10.18512/19806477/rbms.v17n1p76-90.

SINGH, B. Are nitrogen fertilizers deleterious to soil health? Agronomy, v.8, art.48, 2018. DOI: https://doi.org/10.3390/ agronomy 8040048 .

SORATTO, R.P.; PEREIRA, M.; COSTA, T.A.M. da; LAMPERT, V. do N. Fontes alternativas e doses de nitrogênio no milho safrinha em sucessão à soja. Revista Ciência Agronômica, v.41, p.511-518, 2010. DOI: https://doi.org/10.1590/S1806-66902010000400002. 